\title{
Metody poprawy właściwości eksploatacyjnych złączy spawanych
}

\section{Methods for improvement of weld joints operational properties}

\section{Streszczenie}

W pracy przedstawiono potencjalne ograniczenia stosowania materiałów na instalacje energetyczne. Zawarto zestawienie możliwych konstrukcyjnych i technologicznych zabiegów okołospawalniczych mogących poprawić właściwości złączy spawanych. Wskazano, że jest to szczególnie ważne w nowoczesnych materiałach konstrukcyjnych, do których należą stopy o wysokiej zawartości niklu i stale energetyczne. Wymieniono też przyczyny, dla których stosowanie tych zabiegów może być konieczne.

\section{Abstract}

The paper presents a number of potential limitations in the application of materials for power facilities. The list of possible structural and technological operations related to welding processes is presented. These operations can improve different properties of weld joints. It is shown that the operations are particularly important in case of modern structural materials that include nickel rich alloys and steels for power engineering. The reasons that make the application of these operations necessary are also presented.

\section{Wstęp}

Rosnace wymagania wobec materiałów stosowanych na instalacje energetyczne wynikają z konieczności wykorzystywania w tych urządzeniach wysokich ciśnień i temperatur w długotrwałych okresach. Wymaga to znacznego wzrostu sprawności instalacji ciepłowniczych, a więc wzrostu zużycia paliw przy jednoczesnym spadku emisji pyłów, $\mathrm{CO}_{2}, \mathrm{SO}_{2}$ i $\mathrm{NO}_{x}$.

Materiały te i wykonane $z$ nich złącza muszą spełniać liczne, często wzajemnie sprzeczne kryteria, takie jak [1, 2]:

- wysokie i stabilne właściwości wytrzymałościowe w czasie długotrwałej eksploatacji w podwyższonej, zmieniającej się temperaturze (wysoka granica plastyczności i znaczna odporność na różne rodzaje pełzania),

- stabilna, niestarzejąca się struktura w czasie długotrwałej pracy,

Dr inż. Krzysztof Kudła, dr inż. Kwiryn Wojsyk - Politechnika Częstochowska.
- korzystne właściwości fizyczne, tj. niski współczynnik rozszerzalności liniowej/objętościowej, wysoki współczynnik przewodzenia ciepła, niski ciężar właściwy,

- niewielka skłonność do pęknięć kruchych w warunkach pracy,

- nieprzenikalność dla wodoru dyfundującego,

- żaroodporność i odporność na korozję w parze wodnej w jak najwyższej temperaturze przez możliwie długi czas (powyżej 200 tys. h),

- odporność na termomechaniczne zmęczenie niskocykliczne,

- odpowiednie właściwości technologiczne: dobra spawalność, podatność na obróbkę plastyczną na zimno (np. gięcie) i gorąco,

- dostępność asortymentowa,

- umiarkowana cena.

Wymagania te powodują, że poszukiwania materiałów koncentrują się na stosowaniu stopów wysokoniklowych, co niestety jest kosztowne, albo na zastosowaniu odpowiedniej ilości dodatków stopowych w stali energetycznej. Obecnie obserwowane są dwa kierunki rozwoju tych stali - ulepszanie stali niskostopowych bainitycznych przez dodawanie w różnych kombinacjach składników stopowych: $\mathrm{Cr}, \mathrm{Mo}, \mathrm{V}, \mathrm{Ti}, \mathrm{Nb}$, 


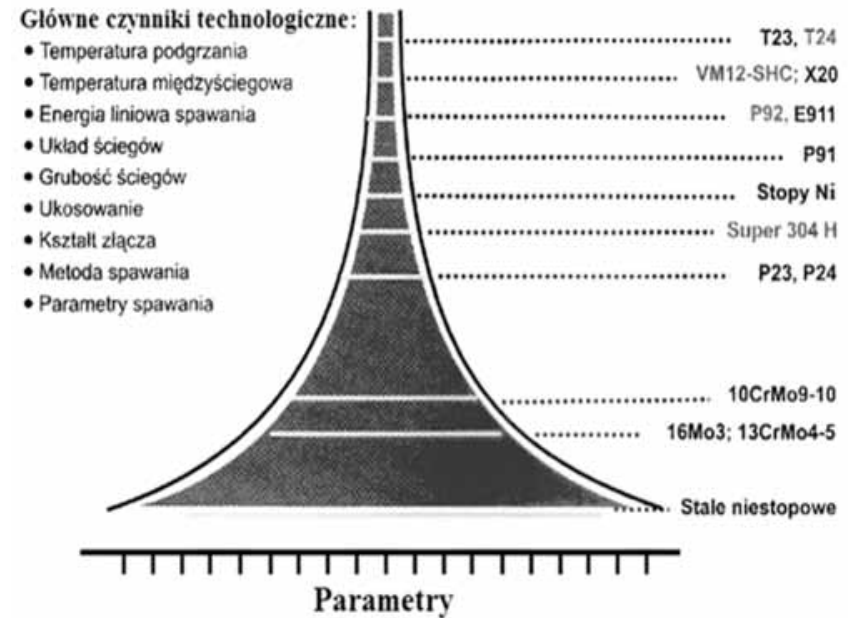

Rys. 1. Możliwości wykonywania poprawnych złączy spawanych stali energetycznych [5]

Fig. 1. The scheme of possibility to carry out good quality welded joints of steel for power facilities [5]

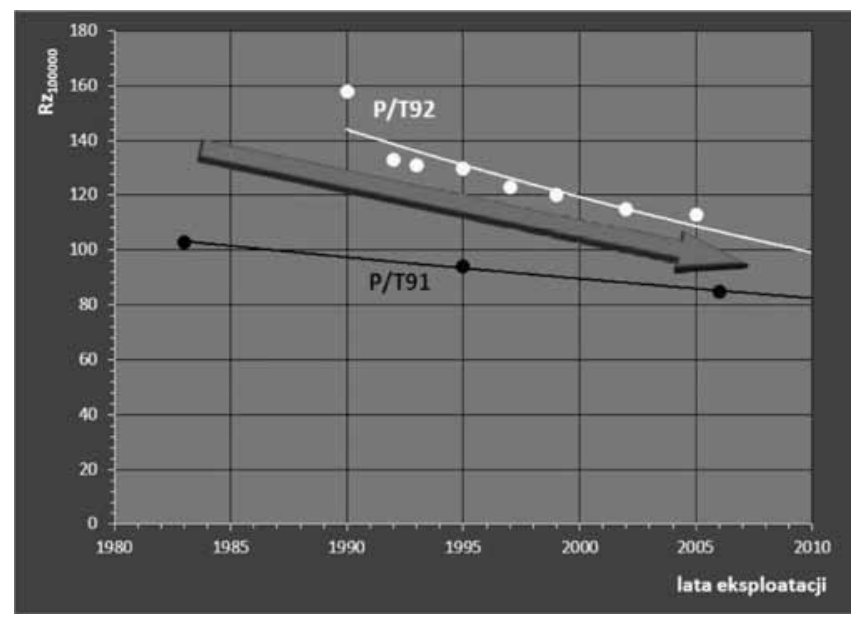

Rys. 2. Prognoza odporności na pełzanie $R_{z / 100}$ stali $P / T 91$ i P/T92 na podstawie badań i publikacji ECCC (Dr P.J. Ennis., Seminarium dot. nowoczesnych stali energetycznych - Rudy Raciborskie 16.04.2008)

Fig. 2. Forecast for creep resistance $R_{z / 100000}$ of $P / T 91$ and $P / T 92$ steels on the basis of ECCC research results and publications (Dr. P.J. Ennis, New steels for power facilities, Rudy Raciborskie 16.04.2008)

$\mathrm{N}, \mathrm{W}, \mathrm{B}$, bądź dodawanie do stali wysokostopowych (zawierających $9 \div 12 \% \mathrm{Cr}$ ) Mo, V, Nb, N, W, B, Co, Cu i innych.

Oba rozwiązania pogarszają spawalność stali w wyniku znacznego zawężenia obszaru wymaganych parametrów przygotowania czynników technologicznych do procesu spawania, co już wstępnie prowadzi do znacznych trudności wykonawczych (rys. 1). Zwiększająca się zawartość pierwiastków stopowych w stali podnosi równoważnik węgla, zatem konieczne staje się nie tylko podgrzewanie wstępne, ale również pospawalnicza obróbka cieplna. Gdy i te zabiegi nie są wystarczające, konieczne jest przewidywanie i zastosowanie dodatkowych konstrukcyjnych i technologicznych operacji wspomagających ograniczone możliwości technologii spawania.

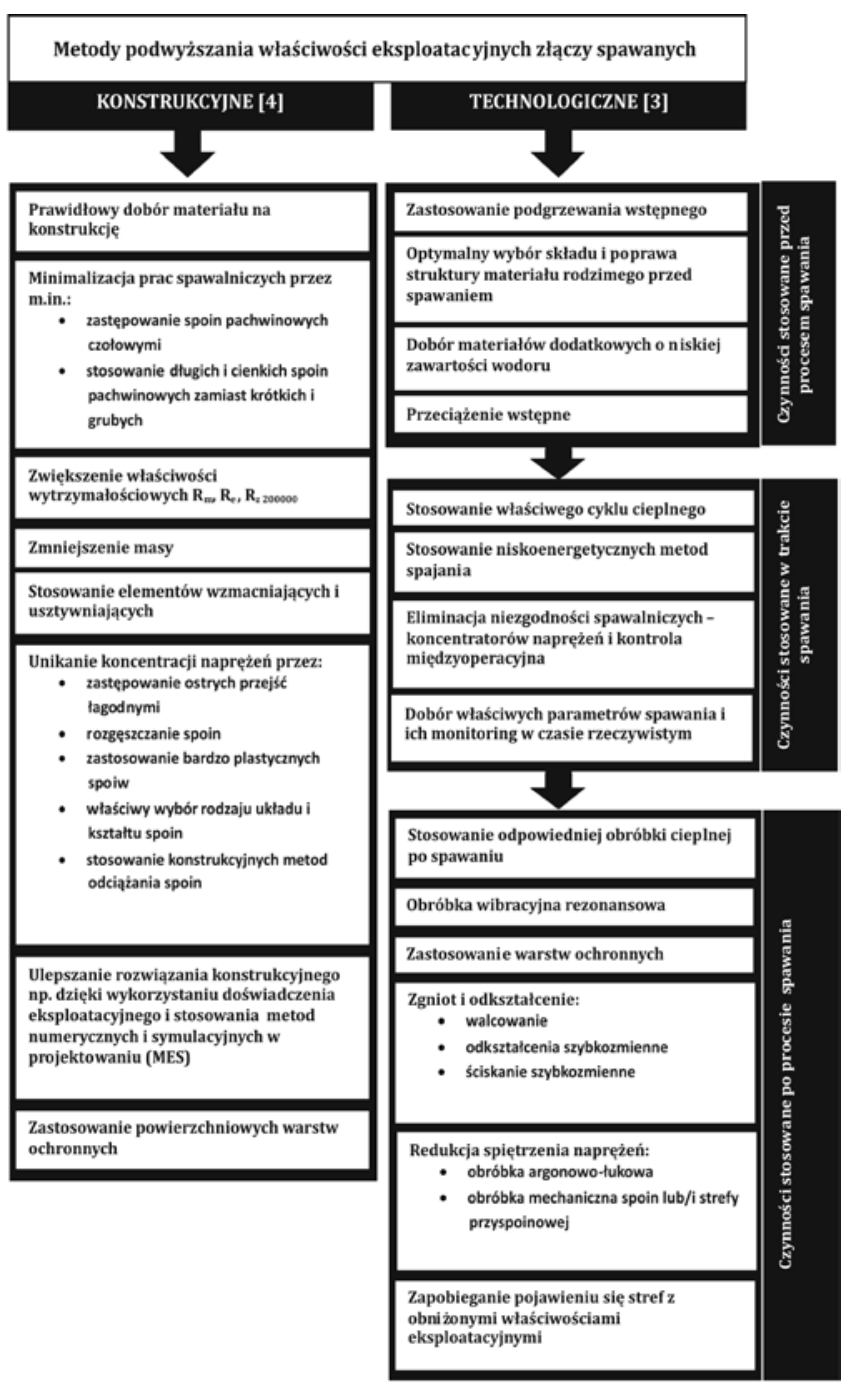

Rys. 3. Metody podwyższania właściwości eksploatacyjnych złączy spawanych

Fig. 3. Methods for improvement of weld joints operational properties

Ostatnie lata przyniosły nie tylko korzyści w stosowaniu stali nowej generacji. Przykładem może być stal P/T24 (7CrMoVTiB10-10), która miała być łatwospawalna, niewymagająca podgrzewania przed spawaniem, a okazała się pułapką inwestycyjno-konstrukcyjno-technologiczną. Wiele inwestycji europejskich zostało opóźnionych lub zagrożonych w wyniku jej zastosowania w odpowiedzialnych miejscach instalacji ciepłowniczych (np. ścian szczelnych) [6, 7].

Zagrożenia mogą również występować przy wprowadzaniu do eksploatacji nowych gatunków stali. Przykładem są stale P/T91 i P/T92, których odporność na pełzanie jest obecnie korygowana w stosunku do odporności deklarowanej przez jej wytwórców (rys. 2).

Oprócz działań poprawiających spawalność stali energetycznych, konieczne jest zatem dokonanie przeglądu i rozważenie zastosowania wszelkich dostępnych zabiegów mogących podnieść jakość i walory eksploatacyjne złączy w spawanych instalacjach energetycznych. Zabiegi te można ogólnie podzielić na konstrukcyjne i technologiczne. Istotne jest, że można je stosować niezależnie od siebie oraz na różnych 


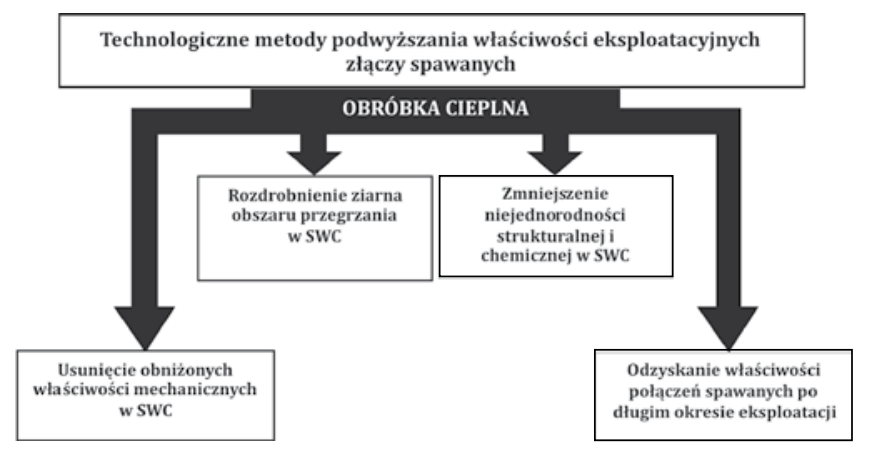

Rys. 4. Technologiczne metody podwyższania właściwości eksploatacyjnych złączy spawanych

Fig. 4. Technological methods for improvement of weld joints operational properties etapach produkcji. Konieczność uwzględniania i wdrażania dodatkowych zabiegów spawalniczych uznawana jest za porażkę inżynierów materiałowych i spawalników (jak pisał Sun Tzu w dziele Sztuka wojenna - „pierwszą porażką ponoszoną w czasie działań wojennych jest konieczność użycia wojska”), należy więc znać, przewidywać i stosować w technologii wykonania energetycznych urządzeń spawanych sposoby mogące umożliwić wykonanie konstrukcji lub wpływające na podniesienie ich jakości. Metody podwyższania właściwości eksploatacyjnych złączy przedstawiono na rysunkach 3 i 4.

\section{Podsumowanie}

Przeprowadzony przegląd właściwości stali energetycznych wskazuje, że istnieje duża liczba zabiegów konstrukcyjnych i technologicznych mogących wpływać na poprawę jakości złączy spawanych, a zatem całej konstrukcji. Są one często kosztowne, pracochłonne lub niewygodne w stosowaniu, jednak należy liczyć się z tym, że zawężające się przedziały parametrów spawania wymuszą ich stosowanie w odpowiedzialnych konstrukcjach, w tym energetycznych.

\section{Literatura}

[1] Golański G., Kępa J.: Nowoczesne stale dla energetyki. Charakterystyka. Wydawnictwo Politechniki Częstochowskiej. Częstochowa 2011.

[2] Hernas A., Wala T., Staszewski M.: Charakterystyka i dobór stali na przegrzewacze w nadkrytycznych parametrach pracy. Inżynieria Materiałowa 3/2009, s. 143.

[3] Czerniak R.: Technologiczne metody podwyższania właściwości mechanicznych spoin i zgrzein. Praca inżynierska 02.02.2012. Promotor dr inż. Kwiryn Wojsyk.
[4] Kudła K., Wojsyk K.: Łaczne i nośne funkcje spoin w nowoczesnych konstrukcjach spawanych. Spajanie 3(9)-4(10). 2010, s. 26

[5] Brózda J.: Seminarium dotyczące stali dla nowoczesnych wysokowydajnych elektrowni i materiałów dodatkowych do ich spawania. Rudy Raciborskie 15.01.2009. Biuletyn Instytutu Spawalnictwa 2/2009, s. 12-15.

[6] Zasuń R.: Pech energetyki: kocioł pęka, woda sika. Gazeta Wyborcza 23.09.2011, s. 26.

[7] Szczepańska M.: EDF nie boi się pękającej stali. Rzeczpospolita 09.12.2011.

Prace zrealizowano w ramach Projektu nr POIG 01.01.02-00-015/08 w Programie Operacyjnym Innowacyjna Gospodarka. Projekt wspóffinansowany przez Unię Europejską ze środków Europejskiego Funduszu Rozwoju Regionalnego,

Financial support of Structural Funds in the Operational Programme - Innovative Economy (IE OP) financed from the European Regional Development Fund - Project No POIG.0101.02-00-015/08 is gratefully acknowledged.

\section{W następnym numerze}

Krzysztof Scheithauer, Katarzyna Scheithauer, Michał Scheithauer

Analiza metod podgrzewania kotłowych paneli gazoszczelnych przed spawaniem przy użyciu promienników podczerwieni i elementów oporowych.

\section{Andrzej Klimpel}

Podstawy teoretyczne cięcia laserowego metali.

\section{Bogdan Pawłowski, Janusz Krawczyk, Piotr Biała, Sławomir Parzych}

Analiza przyczyn pęknięć w obszarze złącza rura-zwornik w rurach płuczkowych stosowanych w wiertnictwie. 